\title{
Reactions to Empire
}

\author{
Sacred Texts in their Socio-Political Contexts \\ Ed. by John Anthony Dunne and Dan Batovici
}

[Reaktionen auf das Kaiserreich. Heilige Texte in ihrem sozial-politischen Kontext.]

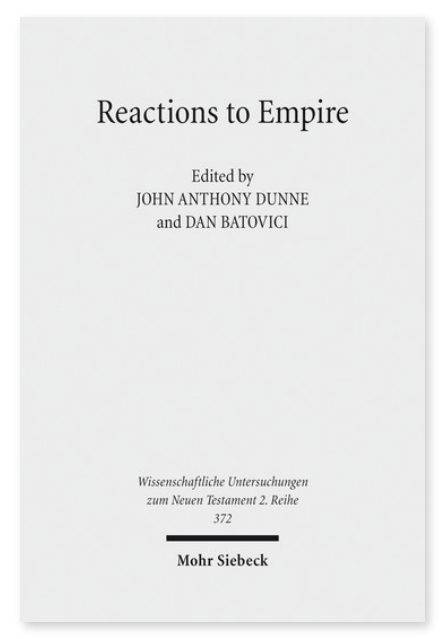

2014. XII, 203 Seiten. WUNT II 372

ISBN 978-3-16-153414-0

DOI 10.1628/978-3-16-153414-0

eBook PDF 79,00€

ISBN 978-3-16-153413-3

fadengeheftete Broschur 79,00€
Veröffentlicht auf Englisch.

Die Beiträger dieses Bandes beleuchten verschiedene Beispiele theologisch-politischer Visionen maßgeblicher Texte aus der Zeit des zweiten Tempels und des rabbinischen Judentums, sowie des frühen Christentums und bieten damit eine breitere Perspektive des Topos »heilige Texte in ihrem Kontext«. Statt einer enggefassten Untersuchung der »politischen Absichten« eines einzelnen Textes oder einer Sammlung von Texten, behandelt der Band ein weites Feld von Texten, aus verschiedenen Textkorpora, mit ihrem jeweiligen Kontext. Deren Gegenüberstellung, sowie die der jeweiligen wissenschaftlichen Ansätze der Aufsätze, liefern neue Einblicke. Jeder der Aufsätze in diesem Band befasst sich mit der Unterdrückung durch imperiale Ideologie und dem Ausmaß, bis zu dem die Verfasser dieser heiligen Texte den politischen Kontext mit einbezogen. Die Texte nähern sich dem Thema der imperialen Ideologie an, einige erläutern insbesondere die Reaktionen auf das römische Reich.

\section{Inhaltsübersicht}

Loren T. Stuckenbruck: A Place for Socio-Political Oppressors at the End of History? Eschatological Perspectives from 1 Enoch - Amanda M. Davis Bledsoe: Attitudes Toward Seleucid Imperial Hegemony in the Book of Daniel - Nadav Sharon: Between Opposition to the Hasmoneans and Resistance to Rome: The Psalms of Solomon and the Dead Sea Scrolls - Matthew V. Novenson: What the Apostles Did Not See - Christoph Heilig: Methodological Considerations for the Search of CounterImperial »Echoes « in Pauline Literature - Alexander P. Thompson: Thwarting the Enemies of God: Contrasting the Death of Herod and the Resurrection of Jesus in Luke-Acts - David I. Starling: "She Who Is in Babylon«: 1 Peter and the Hermeneutics of Empire - Brandon Walker: The Forgotten Kingdom: Miracle, the Memory of Jesus, and Counter-Ideology to the Roman Empire - Candida R. Moss: Resisting Empire in Early Christian Martyrdom Literature - Bernie Hodkin: Theologies of Resistance: A Reexamination of Rabbinic Traditions about Rome

Dan Batovici Born 1976; 2009 graduated Classics in Bucharest; taught MPhil in Theology and Religious Studies in Cambridge; research MPhil in Theology and Religious Studies in St Andrews; currently a PhD candidate at KU Leuven.

John Anthony Dunne Born 1986; 2008 BA, Biola University; 2010 MA, Talbot School of Theology; 2011 MA, Talbot School of Theology; 2016 PhD, University of St Andrews; currently Assistant Professor of New Testament, Bethel Seminary (St. Paul, $\mathrm{MN})$.

Jetzt bestellen:

https://mohrsiebeck.com/buch/reactions-to-empire-9783161534140?no_cache=1

order@mohrsiebeck.com

Telefon: +49 (0)7071-923-17

Telefax: +49 (0)7071-51104 